\title{
技術報文
}

低温下におけるペルオキシダーゼを用いたオレンジ II 退色反応の活性化

\author{
東 輝*・森田 みゆき*,\#
}

\section{Activation of Orange II Decoloration Reaction with Peroxidase Under Low Temperature}

\author{
Akira Higashi* and Miyuki Morita*,\# \\ *Hokkaido University of Education Sapporo, Ainosato 5-3-1, Kita-ku, Sapporo 002-8502, Japan
}

\begin{abstract}
Decoloration of Orange II catalyzed horseradish peroxidase (HRP) with activator as $p$-iodophenol, sodium nonanoyloxybenzenesulphonate (NOBS) and sodium $p$-phenolsufonate under low temperature was studied kinetically. Decoloration rate constant $(k)$ that can prevent dye transfer of Orange II $\left(k=2.0 \mathrm{~min}^{-1}\right)$ was not obtained in $3.4 \times 10^{-8} \mathrm{M}$ HRP without activator. Optimum condition using $p$-iodophenol was $\mathrm{pH} 8.9$ Carmody buffer and $5.0 \times 10^{-5} \mathrm{M} p$ iodophenol. Optimum $\mathrm{pH}$ using NOBS and sodium $p$-phenolsufonate were 10.1 and 10.3 respectively. Decoloration rate constant decreased with increase in the concentration NOBS. $k=2.0 \mathrm{~min}^{-1}$ was not reached unless high sodium $p$ phenolsulfonate. Therefore, it was found that the use of $p$-iodophenol appears optimal.

Decoloration reaction of Orange II using HRP with $p$-iodophenol and sodium percarbonate to prevent dye transfer was optimized under low temperature. The activation energy of decoloration of Orange II using HRP with $p$-iodophenol was $1 / 2-1 / 3$ of those without activator and using sodium percarbonate.
\end{abstract}

(Received 24 September, 2013 ; Accepted 28 January, 2014)

\section{1. 緒 言}

市販衣料用洗濯洗剂には移染防止や, 污れの分解を目 的として漂白剤を含有しているものがある。一般的には 酸素系漂白剂の一つである過炭酸ナトリウムが用いられ ており，過炭酸ナトリウムを用いた染料の分解反応 $[1] や$, 酸素系漂白剂の染料退色機構の解析が行われている[2-3] 過炭酸ナトリウム最適反応条件は高温, 強アルカリであ るため, 最適条件下では繊維の脆化[4-5]などの課題があ る.ささに, 最適条件以外では反応速度も比較的遅いた め, 移染防止は難しい.

また, 衣料用洗剤には洗浄力を高め, 環境負荷の低減 を目的として酵素を添加しているものがある. 添加され ているプロテアーゼ, リパーゼ, アミラーゼなどの酵素 はタンパク質や脂質, デンプンを主に分解する [6]. 我々 は, 酸化還元酵素であるペルオキシダーゼ(POD)が室温, 弱アルカリ領域で染料を素早く退色させることを見出し た[7-8]. さらに, PODへの洗剂成分の添加の影響[9]や, 移染防止について $[10]$ 洗剤添加用酵素としての実用化の 検討を行ってきた.

一方, 北海道などの寒冷地における冬季の洗濯は, 液 温が夏季と比較して大きく低下すると考えられる．その

\# corresponding author

* 北海道教育大学
ため, POD を洗剤添加用酵素として使用するならば，低 温下でも染料退色反応が進行する必要がある.

そこで, 本研究では, 低温下での染料の退色反応を活 性化させることを目的として, 西洋ワサビ由来 POD (HRP) の活性化劑として用いられている $p$-ヨードフェノール, 過炭酸ナトリウムの漂白活性化剂を用いて, 低温下にお けるオレンジ II 退色反応の活性化について検討した。

\section{2. 実 験}

\section{1 試薬および装置}

西洋ワサビ由来ペルオキシダーゼ(HRP) (和光純薬) の 濃度は, モル吸光係数 $1.02 \times 10^{5} \mathrm{~mol}^{-1} \mathrm{dm}^{3} \mathrm{~cm}^{-1}(403 \mathrm{~nm})[11]$ を用いて算出し, 超純水で希釈して使用した. 色素はオ レンジII (関東化学, 鹿 1 級)を特に精製せずそのまま使 用した。活性化㓣として, $p$-ヨードフェノール(和光純薬, 一級), ノナノイルオキシベンゼンスルホン酸ナトリウム (NOBS, 常法により合成), $p$-フェノールスルホン酸ナト リウム二水和物 (和光純薬)を使用した。 その他の試薬は 全て試薬特級を使用した. 水はイオン交換水を一回蒸留 し，ミリポアで超純水処理したものを用いた.

吸光度の測定には日立製紫外可視分光光度計 U-2010, 日立 131-0040 温度表示付恒温セルホールダを使用し, 光 路長 $1 \mathrm{~cm}$ の石英セルを用いた. 


\section{2 操作}

HRP を用いたオレンジ II の分解反応では，石英セルに pH 5.5 から 12.0 Carmody 緩衝溶液または pH 9.0 Tris/ $/ \mathrm{HCl}$ 緩衝溶液 $1.95 \times 10^{-3} \mathrm{dm}^{3}, \quad 1.0 \times 10^{-5} \mathrm{M}$ オレンジ II $0.15 \times$ $10^{-3} \mathrm{dm}^{3}$, 活性化剂 $0.3 \times 10^{-3} \mathrm{dm}^{3}, 3.4 \times 10^{-7}$ M HRP $0.3 \times$ $10^{-3} \mathrm{dm}^{3}$ を加え, 摚拌の後, 過酸化水素をインジェクター で $0.3 \times 10^{-3} \mathrm{dm}^{3}$ 注入して反応を開始させた，過炭酸ナト リウムを用いたオレンジ II の分解反応では, 石英セルに $\mathrm{pH} 11.5 \mathrm{Na}_{2} \mathrm{HPO}_{4} / \mathrm{NaOH}$ 緩衝液を $2.25 \times 10^{-3} \mathrm{dm}^{3}, 1.0 \times 10^{-5} \mathrm{M}$ オレンジ II $0.15 \times 10^{-3} \mathrm{dm}^{3}, 2.0 \mathrm{M}$ 炭酸ナトリウム $0.3 \times$ $10^{-3} \mathrm{dm}^{3}$ を加え, 擋拌し, $3.0 \mathrm{M}$ 過酸化水素をインジェク ターで $0.3 \times 10^{-3} \mathrm{dm}^{3}$ 注入して反応を開始させた。両分解 反応ともオレンジ II の最大吸収波長 $(485 \mathrm{~nm})$ の吸光度の 経時変化を測定した，反応温度は 5 から $20^{\circ} \mathrm{C}$ とした。 た，図および表中の試薬濃度はいずれも終濃度を示す。

HRP のオレンジ II の退色反応は擬一次反応であること が確認されている $[8]$. そのため, 色素の退色曲線から以 下の擬一次反応速度式を用いて色素の退色反応に抢ける 退色速度定数 $k$ を算出した。

$$
\ln \left(C_{0} / C_{\mathrm{t}}\right)=k \cdot t
$$

ここで, $k\left(\mathrm{~min}^{-1}\right)$ は退色速度定数, $C_{0}$ はオレンジ II の初濃 度, $C_{\mathrm{t}}$ は反応時間 $t$ に扔けるオレンジ II の濃度である.

\section{3. 結果および考察}

\section{1 活性化剤を用いたオレンジ II 退色反応の活性化}

HRP を用いたオレンジII 退色反応における各温度の影 響を Fig. 1 に示す。本研究は洗郕用添加䤉素としての実用 化を目的としているため, 使用する酵素の量を低減させ る必要がある. 本研究では HRP の濃度を前報[12]で用い た HRP 濃度に対し， $1 / 10$ の $3.4 \times 10^{-8} \mathrm{M}$ とした. $3.4 \times$

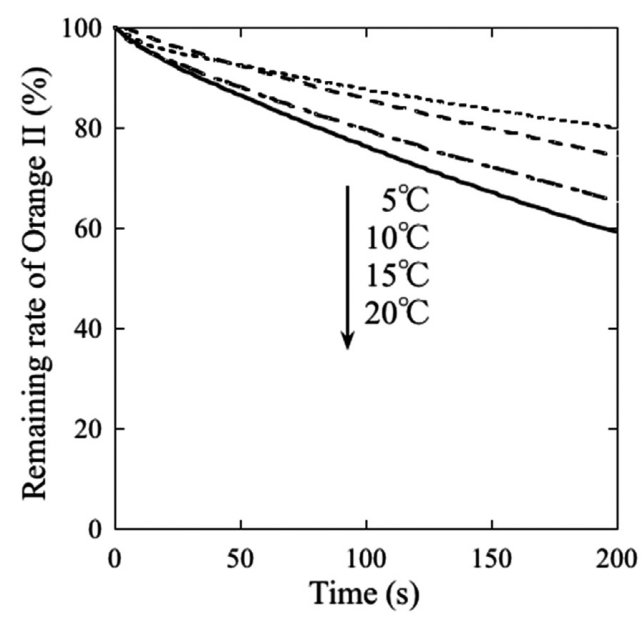

Fig. 1 Effect of temperature on decoloration curve of Orange II.

$[$ Buffer $]=\mathrm{pH} 9.0$ Tris $/ \mathrm{HCl}$, [Orange II $]=5.0 \times 10^{-5} \mathrm{M}$, $[\mathrm{HRP}]=3.4 \times 10^{-8} \mathrm{M},\left[\mathrm{H}_{2} \mathrm{O}_{2}\right]=7.5 \times 10^{-4} \mathrm{M}$.
$10^{-8} \mathrm{MHRP}, \mathrm{pH} 9.0 \mathrm{Tris} / \mathrm{HCl}$ 緩衝液で反応させたところ, 反応温度が低下するに従い, 反応速度が低下した，その ため, 移染防止, $5^{\circ} \mathrm{C}$ での退色反応の活性化のために退色 条件の最適化が必要であることがわかった.

まず， $20^{\circ} \mathrm{C}$ での各種活性化剂の効果を検討した。

HRP を用いたオレンジ II 退色反応で, 各活性化剂共存 及び非共存下に扔ける $\mathrm{pH}$ の影響を検討した，既報をもと に $p$-ヨードフェノールの濃度は, $5.0 \times 10^{-5} \mathrm{M}[13]$, NOBS の濃度は $6.7 \times 10^{-4} \mathrm{M}[12]$ とした. $p$-フェノールスルホン 酸ナトリウムは, NOBS と過酸化水素が反応し, NOBS と 等量の $p$-フェノールスルホン酸ナトリウムが発生するた め, NOBS と同濃度の $6.7 \times 10^{-4} \mathrm{M}$ とした。

Fig. 2 に結果を示す. Carmody 緩衝液を用いた場合, 活 性化剂添加, 非添加に関わらず $\mathrm{pH}$ 上昇と共に退色速度定 数が増加した。活性化剂非共存時に $\mathrm{pH} 10.3(k=$ $\left.0.214 \mathrm{~min}^{-1}\right), p$-ヨードフェノール共存時に $\mathrm{pH} 8.9(k=$ $\left.4.44 \mathrm{~min}^{-1}\right)$, NOBS 共存時に $\mathrm{pH} 10.1\left(k=0.198 \mathrm{~min}^{-1}\right), p$-フ ノールスルホン酸ナトリウム共存時に $\mathrm{pH} 10.3(k=$ $0.215 \mathrm{~min}^{-1}$ )でそれぞれ退色速度定数が最大となった. 活 性化剛を添加することで HRP と反応する水素供与体がオ レンジII から活性化剤に置き代わった．HRP に対する水 素供与体へのなりやすさ, すなわち, ラジカル生成のし やすさは, 酸化還元電位及び酸解離定数に依存するため [14]，よりラジカルになりやすい活性化剤を共存するこ とで最適 $\mathrm{pH}$ が変化したと考えられる. 前報[10]で移染防 止可能な反応速度定数は $2.0 \mathrm{~min}^{-1}$ であることを明らかに しているが, $p$-ヨードフェノールを共存させることで最 大退色速度定数 $4.44 \mathrm{~min}^{-1}$ となった. 活性化剂非共存時, NOBS 及び $p$-フェノールスルホン酸ナトリウム共存時は

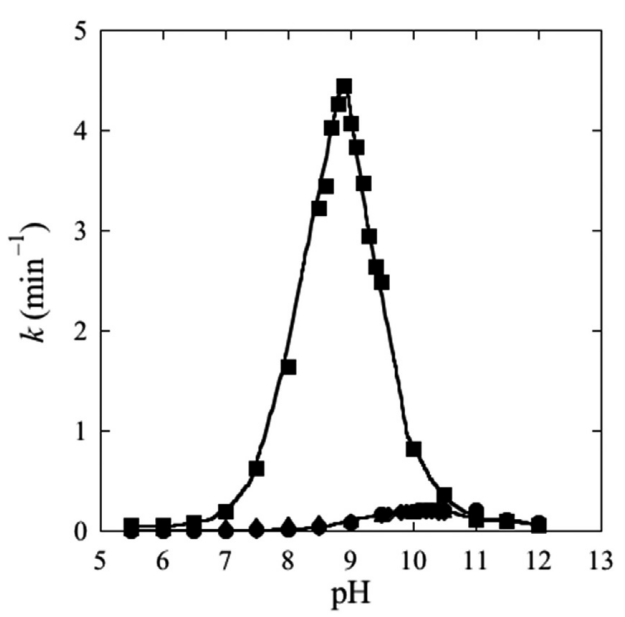

Fig. 2 Effect of $\mathrm{pH}$ on decoloration rate constant of Orange II.

$[$ Buffer $]=$ Carmody, $[$ Orange II $]=5.0 \times 10^{-5} \mathrm{M},[\mathrm{HRP}]=$ $3.4 \times 10^{-8} \mathrm{M}, 20^{\circ} \mathrm{C}$, : No activator $\left(\left[\mathrm{H}_{2} \mathrm{O}_{2}\right]=7.5 \times\right.$ $\left.10^{-4} \mathrm{M}\right), \boldsymbol{\square}:$ With $p$-iodophenol $\left(\left[\mathrm{H}_{2} \mathrm{O}_{2}\right]=7.5 \times 10^{-4} \mathrm{M}\right.$, $[p$-iodophenol $\left.]=5.0 \times 10^{-5} \mathrm{M}\right), \diamond$ : With NOBS $\left(\left[\mathrm{H}_{2} \mathrm{O}_{2}\right]=3.0 \times 10^{-3} \mathrm{M},[\mathrm{NOBS}]=6.7 \times 10^{-4} \mathrm{M}\right), \boldsymbol{\Delta}:$ With sodium $p$-phenolsulfonate $\left(\left[\mathrm{H}_{2} \mathrm{O}_{2}\right]=3.0 \times 10^{-3} \mathrm{M}\right.$, [sodium $p$-phenolsulfonate] $\left.=6.7 \times 10^{-4} \mathrm{M}\right)$. 
$k=2.0 \mathrm{~min}^{-1}$ 以下であった. $p$-ヨードフェノールを添加す ることで, 最適 $\mathrm{pH}$ が中性側にシフトし, 退色速度定数が 20.7 倍となり, オレンジ II 退色反応が活性化された. NOBS $p$-フェノールスルホン酸ナトリウムを添加した場合は,

最適 $\mathrm{pH}$ はほとんど変化なく, 退色速度定数はむしろわず かに低下した。

以上より, 最適 $\mathrm{pH}$ は $p$-ヨードフェノール共存時は pH 8.9 Carmody 緩衝液, NOBS 共存時は pH 10.1 Carmody 緩衝液, $p$-フェノールスルホン酸ナトリウム共存時は pH 10.3 Carmody 緩衝液とした.

次に, オレンジ II 退色反応における活性化剂濃度の影 響について検討した. Fig. 3 に退色曲線を示す. $p$-ヨード フェノールの濃度の増大と共にオレンジ II がすみやかに 退色した. しかし, $7.0 \times 10^{-5} \mathrm{M}$ から $9.0 \times 10^{-5} \mathrm{M}$ にかけて

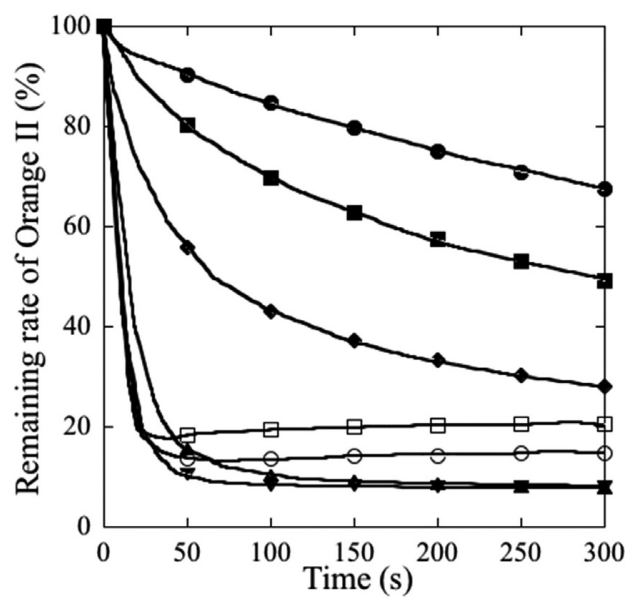

Fig. 3 Effect of $p$-iodophenol concentration on decoloration curve of Orange II.

$[$ Buffer $]=\mathrm{pH} 8.9$ Carmody, [Orange II $]=5.0 \times 10^{-5} \mathrm{M}$, $[\mathrm{HRP}]=3.4 \times 10^{-8} \mathrm{M},\left[\mathrm{H}_{2} \mathrm{O}_{2}\right]=7.5 \times 10^{-4} \mathrm{M}, 20^{\circ} \mathrm{C}$,

$[p$-iodophenol $]: 0 \mathrm{M}, \mathbf{\square}: 1.0 \times 10^{-6} \mathrm{M}, \mathbf{\square}: 5.0 \times$ $10^{-6} \mathrm{M}, \boldsymbol{\Delta}: 3.0 \times 10^{-5} \mathrm{M}, \boldsymbol{\nabla}: 5.0 \times 10^{-5} \mathrm{M}, \bigcirc: 7.0 \times$ $10^{-5} \mathrm{M}, \square: 1.0 \times 10^{-4} \mathrm{M}$.

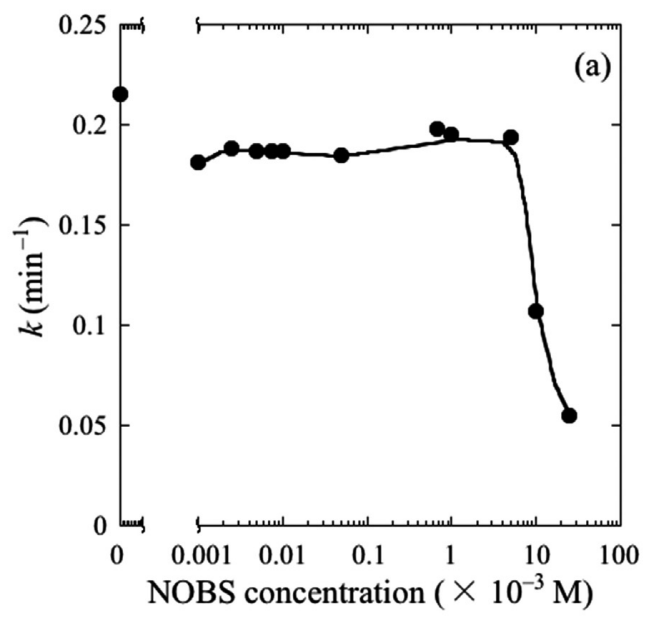

反応開始 20 秒までの変化の割合が小さくなった. $p$-ヨー ドフェノール濃度 $9.0 \times 10^{-5} \mathrm{M}$ で退色速度定数が最大 $(k=$ $\left.5.33 \mathrm{~min}^{-1}\right)$ となり, $1.0 \times 10^{-4} \mathrm{M}$ で減少した。一方，退色反 応開始 5 分後のオレンジ II 残留率は $p$-ヨードフェノール 濃度増大と共に減少するが, $7.0 \times 10^{-5} \mathrm{M} p$-ヨードフェノー ル以上では残留率が増大した. HRP 及び $p$-ヨードフェ ノールを含む溶液に過酸化水素を添加すると, $p$-ヨード フェノールの酸化生成物が発生し，オレンジII の測定波 長付近にも吸収を有することから [13]，同様の酸化生成 物が生成し, $485 \mathrm{~nm}$ の吸光度が上昇したと考えられる. 従って, $p$-ヨードフェノールの最適濃度を $5.0 \times 10^{-5} \mathrm{M}$ と した。

オレンジII 退色速度定数におけるNOBS 濃度及び $p$-フェノールスルホン酸ナトリウムの影響を Fig. 4 に示す. NOBS を共存させた場合, $5.0 \times 10^{-3} \mathrm{M}$ までは退色速度定 数の変化はなかったが, $1.0 \times 10^{-2} \mathrm{M}$ 以上では退色速度定 数が大きく低下した. 一方で, $p$-フェノールスルホン酸 ナトリウムは濃度増大と共に退色速度定数が上昇し, $5.0 \times 10^{-2} \mathrm{M}$ では $p$-フェノールスルホン酸ナトリウム非共 存時の 11.3 倍となった. モミガラ由来 POD (RPO)を用い た NOBS 共存下でのオレンジ II の退色反応では NOBS が 過酸化水素によって $p$-フェノールスルホン酸ナトリウム と有機過酸に分解され, $p$-フェノールスルホン酸ナトリ ウムが RPO の活性化剂として作用し, 退色反応を促進し ていることを明らかにした[13]. しかし, HRP と NOBS を共存させた場合, オレンジ II の退色速度定数は増加し なかった．また, $p$-フェノールスルホン酸ナトリウムを 共存した場合, 濃度上昇と共に退色速度定数が上昇した が, $p$-ヨードフェノールを添加した場合と比較すると反 応が遅かった。

以上から, $3.4 \times 10^{-8} \mathrm{MHRP}$ を用いたオレンジ II の退色 反応の活性化には, $5.0 \times 10^{-5} \mathrm{M} p$-ヨードフェノールを最 適条件とした.

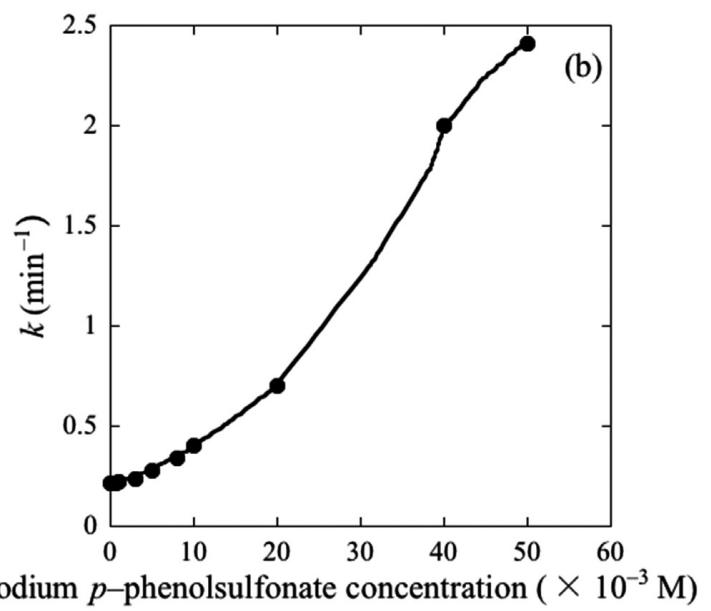

Fig. 4 Effect of activator concentration on decoloration rate constant of Orange II.

[Orange II $]=5.0 \times 10^{-5} \mathrm{M},[\mathrm{HRP}]=3.4 \times 10^{-8} \mathrm{M},\left[\mathrm{H}_{2} \mathrm{O}_{2}\right]=3.0 \times 10^{-3} \mathrm{M}, 20^{\circ} \mathrm{C}$, (a) : With NOBS $([\mathrm{Buffer}]=\mathrm{pH} 10.1$ Carmody), (b) : With sodium $p$-phenolsulfonate ([Buffer $]=\mathrm{pH} 10.3$ Carmody). 


\section{2 低温下におけるオレンジ II 退色反応の活性化}

$5^{\circ} \mathrm{C}$ におるオレンジII 退色反応の最適化のため $p$-ヨードフェノール濃度について検討した. 結果を Fig. 5 に示す. $p$-ヨードフェノール濃度を $0 \mathrm{M}$ から $1.0 \times 10^{-4} \mathrm{M}$ まで変化させたところ, $9.0 \times 10^{-5} \mathrm{M}$ で二量体と推測され る沈殿物が生じた. 従って, $9.0 \times 10^{-5} \mathrm{M} て ゙$ 退色速度定数 が最大となり, 時間経過によるオレンジ II 残留率の増大 も見られなかったことから， $p$-ヨードフェノール最適濃 度を $9.0 \times 10^{-5} \mathrm{M}$ と決定した。

次にオレンジ II 退色反応における反応温度の影響につ いて HRP 系への $p$-ヨードフェノール共存の有無, および 過炭酸ナトリウムを用いた場合で検討した。いずれも温 度上昇と共に退色速度定数は増加した. $5^{\circ} \mathrm{C}$ の条件下にお ける退色速度定数は, 活性化剂非共存時に $0.0270 \mathrm{~min}^{-1}$, 過炭酸ナトリウムを用いた場合には $0.0492 \mathrm{~min}^{-1}$ となり, オレンジII 移染防止が可能な退色速度定数は得られな かったが, $p$-ヨードフェノール共存時には, 退色速度定 数は $3.58 \mathrm{~min}^{-1}$ となった. 従って, $3.4 \times 10^{-8} \mathrm{MHRP} に 9.0$ $\times 10^{-5} \mathrm{M} p$-ヨードフェノールを共存させることによって低 温下でもオレンジ II 退色反応が速やかに進行することが わかった。

Fig. 6 に退色速度定数のアレニウスプロット, Table 1 に 活性化エネルギーを示す. $9.0 \times 10^{-5} \mathrm{M} p$-ヨードフェノー ルを共存した $3.4 \times 10^{-8} \mathrm{MHRP}$ を用いた場合, 活性化エネ ルギーは $18.0 \mathrm{~kJ} / \mathrm{mol}$ となった. 同様に活性化剂非共存 HRP

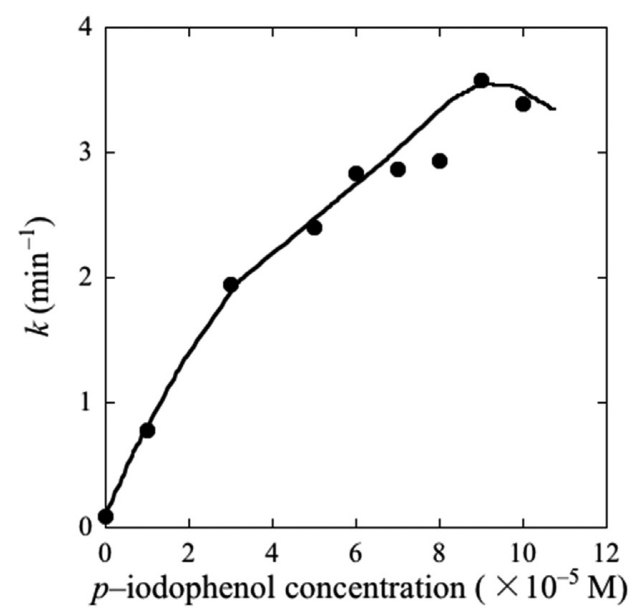

Fig. 5 Effect of $p$-iodophenol concentration on decoloration rate constant of Orange II.

$[$ Buffer $]=\mathrm{pH} 8.9$ Carmody, [Orange II] $=5.0 \times 10^{-5} \mathrm{M}$, $[\mathrm{HRP}]=3.4 \times 10^{-8} \mathrm{M},\left[\mathrm{H}_{2} \mathrm{O}_{2}\right]=7.5 \times 10^{-4} \mathrm{M}, 5^{\circ} \mathrm{C}$.
で $52.1 \mathrm{~kJ} / \mathrm{mol}, \quad 0.2 \mathrm{M}$ 過炭酸ナトリウムで $40.0 \mathrm{~kJ} / \mathrm{mol}$ と なったことから, $9.0 \times 10^{-5} \mathrm{Mp}$-ヨードフェノールを共存 させることでオレンジ II 退色反応が活性化されたことが わかった.

\section{4. 総 括}

低温下における HRP 及び各種 POD 活性化剂共存系を 用いてオレンジ II 退色反応の活性化について速度論的に 検討した. HRPに $p$-ヨードフェノールを共存させた場合, 最適 $\mathrm{pH}$ は $\mathrm{pH} 8.9$ Carmody 緩衝液, 最適 $p$-ヨードフェノー ル濃度は $5.0 \times 10^{-5} \mathrm{M}$ となった. $p$-ヨードフェノール $7.0 \times$ $10^{-5} \mathrm{M}$ 以上では酸化生成物と思われる物質が生成すると推 測された，HRPにNOBSを共存させた場合, 最適 $\mathrm{pH}$ は pH 10.1 Carmody 緩衝液となった. NOBS の濃度を増大さ せると, $1.0 \times 10^{-2} \mathrm{M}$ 以上でオレンジ II 退色速度定数が大 きく低下した. $p$-フェノールスルホン酸ナトリウムを共 存させた場合, 最適 $\mathrm{pH}$ は $\mathrm{pH} 10.3$ Carmody 緩衝液となっ た. $p$-フェノールスルホン酸ナトリウム濃度上昇と共に オレンジII 退色速度定数が増加したが, $p$-ヨードフェノー ルよりも高濃度でなければ反応が速やかに進行しなかっ た. 従って, HRPのオレンジII 退色反応には, $p$-ヨード フェノールを使用することが最適と考えられた.

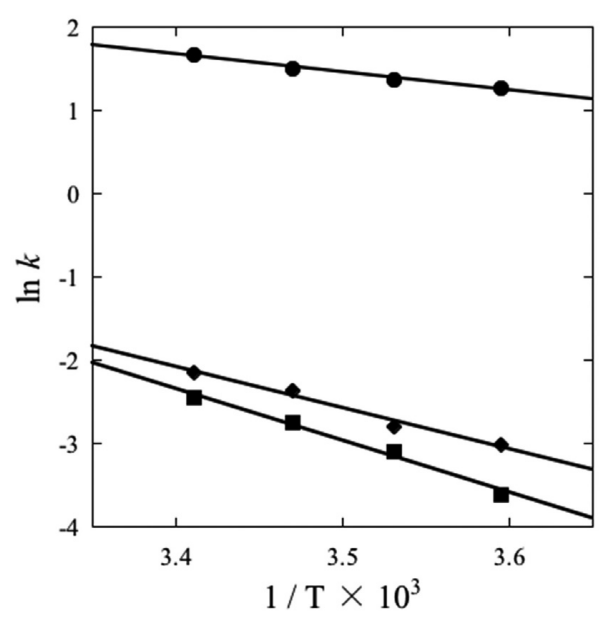

Fig. 6 Arrhenius plot of decoloration of Orange II. [Orange II] $=5.0 \times 10^{-5} \mathrm{M}, \mathrm{O}: \mathrm{HRP}+p$-iodophenol ([Buffer] $=8.9$ Carmody, $[\mathrm{HRP}]=3.4 \times 10^{-8} \mathrm{M},\left[\mathrm{H}_{2} \mathrm{O}_{2}\right]=$ $7.5 \times 10^{-4} \mathrm{M},[p$-iodophenol $\left.]=9.0 \times 10^{-4} \mathrm{M}\right), \mathbf{\square}: \mathrm{HRP}$ $\left([\right.$ Buffer $]=8.9$ Carmody, $[\mathrm{HRP}]=3.4 \times 10^{-8} \mathrm{M},\left[\mathrm{H}_{2} \mathrm{O}_{2}\right]=$ $\left.7.5 \times 10^{-4} \mathrm{M}\right),>$ : Sodium percarbonate $([\mathrm{Buffer}]=\mathrm{pH}$ 11.5 $\left.\mathrm{Na}_{2} \mathrm{HPO}_{4} / \mathrm{NaOH},\left[\mathrm{Na}_{2} \mathrm{CO}_{3}\right]=0.2 \mathrm{M},\left[\mathrm{H}_{2} \mathrm{O}_{2}\right]=0.3 \mathrm{M}\right)$.

Table 1 Activation energy and correlation coefficient.

\begin{tabular}{lcc}
\hline Detergent & Activation energy $\left(\mathrm{kJ} \mathrm{mol}^{-1}\right)$ & $\mathrm{R}^{2}$ \\
\hline HRP $+p$-iodophenol & 18.0 & 0.973 \\
HRP & 52.1 & 0.988 \\
Sodium percarbonate & 40.0 & 0.979 \\
\hline
\end{tabular}


HRP 系における $p$-ヨードフェノール共存及び過炭酸ナ トリウムを用いて $5^{\circ} \mathrm{C}$ でオレンジ II 退色反応を試みた結 果, $9.0 \times 10^{-5} \mathrm{M} p$-ヨードフェノール共存 HRP ではオレン ジ II の退色速度定数は $3.58 \mathrm{~min}^{-1}$ となり, 移染防止が可能 であることがわかった。 この時の退色率は減少しなかっ たことから最適濃度を $9.0 \times 10^{-5} \mathrm{M}$ とした．また， $p$-ヨー ドフェノール共存時の活性化エネルギーは活性化剂非共 存, 過炭酸ナトリウムの約 $1 / 2$ から $1 / 3$ となった.

\section{文 献}

1. R. Ohura, A. Katayama and T. Takagishi, Text. Res. J. 62, 552 (1992).

2. T. Tamura, T. Kubozono, M. Tamura and H. Yoshimura, $J$. Jpn. Oil Chem. Soc., 44, 1086 (1995).

3. T. Tamura, T. Kubozono, M. Tamura and H. Yoshimura, $J$. Jpn. Oil Chem. Soc., 44, 1093 (1995).

4. M. Morita, E. Komatsu, T. Kamidate and H. Watanabe, Sen'i Gakkaishi, 53, 471 (1997).
5. R. Ohura, J. of Home Economics of Japan, 40, 913 (1989).

6. Y. Suzuki, Jpn. Res. Assn. Text. End-Uses, 54, 319 (2013).

7. M. Morita, T. Kamidate, T. Shibata and H. Watanabe, J. Jpn. Oil Chem. Soc., 46, 807 (1997).

8. M. Morita, R. Ito, T. Kamidate and H. Watanabe, Text. Res. J., 66, 470 (1996).

9. M. Morita, E. Yamaguchi, T. Kamidate and H. Watanabe, Jpn. Oil Chem. Soc., 46, 573 (1997).

10. M. Morita, E. Komatsu, T. Kamidate and H. Watanabe, Sen'i Gakkaishi, 53, 289 (1997).

11. B. B. Kim, V. V. Pisarev and A. M. Egorov, Anal. Biochem., 199, 1 (1991).

12. M. Morita, T. Watanabe and A. Higashi, Sen'i Gakkaishi, 69, 147 (2013).

13. T. Kamidate, T. Shibata, H. Watanabe and M. Morita, J. Jpn. Oil Chem. Soc., 47, 1345 (1998).

14. M. Morita, K. Takada, M. Morisaki and E. Komatsu, Sen'i Gakkaishi, 64, 125 (2008). 